Zeszyty Naukowe Szkoły Głównej Gospodarstwa Wiejskiego

Ekonomika i Organizacja Gospodarki Żywnościowej nr 120, 2017: 5-15

DOI 10.22630/EIOGZ.2017.120.35

Maciej Meyer

Wydział Przedsiębiorczości i Towaroznawstwa

Akademia Morska w Gdyni

\title{
Krytyczna analiza paradygmatu innowacyjności
}

\section{Wstęp}

Zagadnienie i problematyka innowacyjności mają i miały zawsze duże znaczenie, niezależnie od poziomu jej implementacji. Innowacyjność może wpływać na przewagę konkurencyjną zarówno państw, jak i korporacji transnarodowych, samorządów, przedsiębiorstw i innych podmiotów. Nie jest ona jednak jedynym czynnikiem warunkującym zwycięstwo w silnie konkurencyjnym środowisku. Jest ona przedmiotem nieustannej troski kolejnych rządów, a stosowne różne rodzaje polityki, które mają ją pobudzić, są tworzone zwłaszcza w okresie różnorodnych reform.

\section{Cele, metody i źródła badań}

Artykuł ten nie zajmuje wyłącznie krytycznego stanowiska wobec paradygmatu innowacyjności. Wskazuje jednak na jej wady, alternatywę i wspiera tezę, która głosi, że innowacyjność wymaga sprzyjających warunków i nie powinna być celem samym w sobie. Okazuje się, że wszelkie zalecenia i programy, które mają stymulować powstawanie innowacji, bez odpowiedniego otoczenia instytucjonalnego i kulturowego nie są wystarczająco skuteczne. Autor stara się to wykazać na przykładzie Rzeczypospolitej Polskiej, Chińskiej Republiki Ludowej i innych państw, pomijając niższy poziom implementacji. Analiza literatury i wybranych przykładów sukcesu oraz rozumowanie bazujące na dedukcji i redukcji są głównymi narzędziami do osiągnięcia tego celu. 


\section{Istota innowacyjności}

Słowo innowacja (z łac. innovatio) oznaczało pierwotnie wprowadzenie czegoś nowego lub nowo wprowadzoną rzecz. Oczywiście z czasem nabrało ono innych znaczeń w zależności od kontekstu, który bywa bardzo szeroki. Zjawisko innowacji towarzyszyło człowiekowi od zawsze, nawet gdy nie miało swojej nazwy. Dotyczy ono jednak nie tylko człowieka i wydaje się być mocno związane z naukami przyrodniczymi, choćby przez wzgląd na ewolucję. Dopiero Solow w 1957 roku wykazał na podstawie danych o gospodarce amerykańskiej, że to innowacje w największym stopniu są odpowiedzialne za rozwój gospodarki.

Istnieje wiele definicji słowa innowacja. Bezcelowe wydaje się poszukiwanie ich wszystkich, na parę przykładów warto jednak zwrócić uwagę. Baruk [2002] podaje, że ,innowacja jest to celowo zaprojektowana przez człowieka zmiana dotycząca produktu (wprowadzenie do produkcji i na rynek wyrobów nowych lub istotnie ulepszonych), metod wytwarzania (zastosowanie w produkcji metod nowych lub istotnie ulepszonych), organizacji pracy i produkcji (nowe rozwiązania organizacyjne $\mathrm{w}$ znaczeniu strukturalnym i procesowym lub istotne udoskonalenie już istniejących) lub metod zarządzania, zastosowana po raz pierwszy w danej społeczności (najmniejszą społeczność tworzą pracownicy danego przedsiębiorstwa) celem osiąnnięcia określonych korzyści społeczno-gospodarczych, spełniających określone kryteria techniczne, ekonomiczne i społeczne". Pomykalski [2001] zwraca uwagę, że innowacja to proces, który obejmuje całość działań, które są związane z kreowaniem pomysłów, powstawaniem wynalazków, a później z wdrażaniem nowych (ulepszonych) produktów, procesów lub usług.

Inne propozycje definicji podkreślają, że:

- „Innowacje odnosi się do jakiegokolwiek dobra, usługi lub pomysłu, który jest postrzegany przez kogoś jako nowy. Pomysł może istnieć od dawna, ale stanowi innowację dla osoby, która go postrzega jako nowy" [Kotler 1994].

- „Innowacja to pierwsze praktyczne wykorzystanie wynalazku”, a „wynalazek to zrozumienie «czegoś» nowego, znalezienie rozwiązania, które nie było znane lub aplikacji, która nie była stosowana. Może to być idea nowego produktu, procesu lub usługi" [Nasierowski 1997].

- „Innowacje (...) to wyszukiwanie dobrych pomysłów i ich urynkowienie. Istotną rolę w tym zakresie odgrywa intuicja - zasadniczy trzon każdej innowacji" [Castenow 1996].

Na podstawie tych kilku przykładów definicji można zauważyć trudność w znalezieniu konkretnego wspólnego mianownika. Edison i inni [2013] przebadali ponad 40 definicji z literatury, pomijając oczywiście autorów polskich i wielu innych. Na tej podstawie doszli do wniosku, że innowacja to: 
- produkcja lub przyjęcie, przyswojenie i eksploatacja nowości o wartości dodanej w sferze gospodarczej lub społecznej,

- odnowienie i rozwijanie produktów, usług i rynków,

- rozwój nowych metod produkcji,

- ustanowienie nowych systemów zarządzania.

Innowacja to zarówno proces, jak i wynik. Taka propozycja definicji pozwala na uchwycenie różnicy między przykładowymi innowacyjnymi produktami swoich czasów - pierwszym telefonem Aleksandra Bella a najnowszym modelem smartfona.

Edison i inni [2013] zwracają uwage na istotne wymiary innowacji: stopień nowości (czy dana innowacja jest nowością dla przedsiębiorstwa, rynku, przemysłu, świata) i rodzaj innowacji (innowacja produktu i usługi czy procesu). Autor tego artykułu proponuje wprowadzenie dodatkowo aspektu czasu i przestrzeni do rozważań o innowacjach, co będzie powodem ich relatywizacji. Czy innowacją jest wynalazek ze Stanów Zjednoczonych, dostępny w Polsce po pięciu latach? Czy innowacją jest wytwarzanie obecnie wędlin w sposób tradycyjny? Czy innowacją jest jogurt, do którego dodano na przykład wyciąg $\mathrm{z}$ aloesu? Autor uważa, że to nie są innowacje. Stawianie takich i podobnych pytań sprawia sporo problemów, które są poruszane w dalszej części artykułu.

Mnogość definicji przekłada się na dużą liczbę rankingów, które są wynikiem prób pomiaru innowacyjności. Są to na przykład: Global Innovation Index, Bloomberg Innovation Index, Global Competitiveness Report, EIU Innovation Ranking, International Innovation Index, World Competitiveness Scoreboard, Innovation Capacity Index. Rankingi te stworzono według określonej, odmiennej metodologii. Metodologie te biorą często pod uwagę aktywność różnych podmiotów w ustanawianiu patentów. Autor wychodzi z założenia, że liczba przyznanych patentów za dany rok nie daje aż tak pełnego obrazu, jak ukazanie dynamiki ich przyznawania, co odzwierciedlają dane w tabeli 1 . Wyraźnie zauważalny jest kryzys lat 2007/2008 w skali całego świata oraz wyjątkowa pozycja Chin.

Wobec faktu, że istnieje wiele definicji innowacji, warto zwrócić uwagę na klasyka Schumpetera, który w XX wieku zapoczątkował badania nad nimi, twierdząc, że innowacje stymulują wzrost gospodarczy. Ujmował to dokładniej, mówiąc, że wzrost jest definiowany przez wprowadzanie „nowych kombinacji” [Schumpeter 1934/2012]. Koncepcja ta zawiera według niego następujące pięć przypadków:

- wprowadzenie do produkcji nowych lub udoskonalonych wyrobów - takich, których nie znają jeszcze konsumenci,

- wprowadzenie nowej metody produkcji, która nie była jeszcze testowana doświadczalnie w danej gałęzi przemysłu, 
- otwarcie nowego rynku zbytu, tzn. takiego, w którym dana gałąź przemysłu jeszcze nie istniała, mimo że sam rynek mógł wcześniej istnieć,

- zdobycie nowych źródeł surowców lub półfabrykatów i to bez względu na to, czy to źródło istniało wcześniej,

- wprowadzenie nowej organizacji jakiegokolwiek przemysłu, na przykład wprowadzenie monopolu lub też jego likwidacja.

\section{Problemy związane z innowacyjnością}

Mnogość różnych definicji i brak jasnych, akceptowanych przez wszystkich kryteriów stanowią poważny problem dla innowacyjności. Nie dotyczy on samego zjawiska per se, ale stan taki może utrudniać powstawanie innowacji, skoro nie jest wyraźnie określone, czym one są. Spora liczba wspomnianych już rankingów, a co za tym idzie - metodologii, wedle których są one układane, świadczy o problemach definicyjnych i braku ostrych kryteriów. Dochodzi do sytuacji, w których istnieją duże różnice w innowacyjności państw, co obrazuje tabela 2, na przykładzie choćby Korei Południowej i Japonii. W niektórych przypadkach to imitacja może zostać uznana według powszechnych definicji za innowację.

Od wielu lat obserwuje się wszędzie w gospodarce i nauce nacisk na tworzenie innowacji, ale równocześnie stworzenie czegoś na miarę toalety, pralki i elektryczności jest współcześnie bardzo trudne. Zapewne jest to związane z efektem podobnym do catch-up przy wzroście PKB, w którym państwom już rozwiniętym trudno jest osiągnąc jego szybkie tempo, państwom rozwijającym

Tabela 2

Porównanie rankingów Bloomberg Innovation Index (BII) i Global Innovation Index (GII) za 2016 rok

\begin{tabular}{|c|c|c|c|c|}
\hline Miejsce & Ranking BII & Wartość BII & Ranking GII & Wartość GII \\
\hline 1 & Korea Południowa & 91,31 & Szwajcaria & 66,3 \\
\hline 2 & Niemcy & 85,54 & Szwecja & 63,6 \\
\hline 3 & Szwecja & 85,21 & Zjednoczone Królestwo & 61,9 \\
\hline 4 & Japonia & 85,07 & Stany Zjednoczone & 61,4 \\
\hline 5 & Szwajcaria & 84,96 & Finlandia & 59,9 \\
\hline 6 & Singapur & 84,54 & Singapur & 59,2 \\
\hline 7 & Finlandia & 83,80 & Irlandia & 59,0 \\
\hline 8 & Stany Zjednoczone & 82,84 & Dania & 58,5 \\
\hline 9 & Dania & 81,40 & Holandia & 58,3 \\
\hline 10 & Francja & 80,39 & Niemcy & 57,9 \\
\hline
\end{tabular}

Źródło: Bloomberg Innovation Index [2016], Global Innovation Index [2016]. 
się (np. Chinom) przychodzi to zaś łatwiej. Problematyczne tutaj wydaje się oczywiście utrzymanie danego tempa wzrostu PKB. Podobnie sytuacja wygląda z długością życia i szybkością podróżowania. Obecne przyrosty nie dorównują tym z początku XX wieku. Może to mieć też związek ze wzrostem wiedzy, ponieważ wraz z jej akumulacją coraz trudniej jest wymyślić coś nowego.

Należy zauważyć, że mimo rosnących nakładów na innowacje i wprowadzania różnych programów, nie przynosi to proporcjonalnych efektów. Jedną z przeszkód może być brak popytu na nie w pewnych okolicznościach, szczególnie ze strony sektora prywatnego. Na przykład Polska jest państwem taniej i dobrej, bo wykształconej siły roboczej (takie zalety były prezentowane nawet Chińczykom w materiałach opracowywanych przez Polską Agencję Informacji i Inwestycji Zagranicznych), stąd „ssanie” na innowacje nie musi być duże. Rodrik [2007] zwraca uwagę, że to nie brak naukowców, inżynierów i laboratoriów naukowo-badawczych lub niewystarczająca ochrona praw własności intelektualnej ograniczają innowacje konieczne do restrukturyzacji gospodarek państw rozwijających się. To właśnie brak popytu ze strony potencjalnych użytkowników w realnej gospodarce ogranicza rozwój innowacji. Jest on słaby, ponieważ przedsiębiorcy postrzegają nowe aktywności jako mało zyskowne. Rozwój technologii i nauki nie przyniesie oczekiwanej dynamiki produkcji bez zapotrzebowania ze strony biznesu.

Kluczowe dla innowacyjności jest zagadnienie patentów, praw własności i praw własności intelektualnej. Były one także bardzo istotne dla inwestycji w państwach uprzemysłowionych w czasach ich intensywnego rozwoju. Rządy Stanów Zjednoczonych, Francji i Wielkiej Brytanii zaczęły ustanawiać prawa patentowe, aby chronić nową wiedzę, wynalazki i postęp technologiczny. Praktyka życia gospodarczego i społecznego wykazała sporo wątpliwości w tej kwestii. Istnieli także myśliciele (np. Thomas Jefferson z USA), którzy uważali, że pomysły nie powinny należeć do jednostek i wspierali ideę publicznych praw własności. Prywatne prawa własności intelektualnej, konieczne zwłaszcza wtedy, gdy łatwo jest powielać technologię (przemysł chemiczny, farmaceutyczny, oprogramowanie komputerowe), w wielu przypadkach tworzy pozycję innowatora nowej technologii zbliżoną do monopolu. Teoria ekonomii wskazuje na duży koszt dla społeczeństwa takich rozwiązań. $Z$ pewnej perspektywy przyczyniają się one też do marnotrawienia zasobów, gdy naśladowcy innowatorów podejmują wysiłki i inwestycje na opracowanie takich samych rozwiązań.

Nieefektywność monopolu i zużywanie zasobów w tym samym celu nie są najważniejszym problemem związanym z systemem patentowym [Chang 2008]. Najbardziej szkodliwy wpływ ma potencjalne blokowanie przepływu wiedzy do krajów technologicznie zacofanych, które potrzebują lepszych technologii, aby rozwijać swoje gospodarki. $Z$ jednej strony sposoby zdobycia zagranicznej 
wiedzy, a z drugiej obrona przed jej niekontrolowanym wypływem zawsze były sednem rozwoju gospodarczego.

Okazuje się, że obecnie rozwinięte gospodarczo kraje nie osiagnęłyby swojego poziomu rozwoju, gdyby same stosowały politykę i instytucje, które polecają krajom rozwijającym się [Chang 2007]. W przeszłości bardzo powszechne były kradzieże patentów, szpiegostwo przemysłowe, uprowadzanie rzemieślników i inne sposoby zdobywania wiedzy, które teraz są nielegalne. Obecnie system intelektualnych praw własności można uznać raczej za przeszkodę technologicznych innowacji. Chang [2008] podaje, że 97\% wszystkich patentów i ogromna większość praw autorskich oraz znaków towarowych jest w posiadaniu bogatych państw. $Z$ tego powodu dalsze wzmacnianie tego systemu praw oznacza coraz większe koszty zdobywania wiedzy przez kraje rozwijające się, zwłaszcza w ramach porozumienia TRIPS. Warto zwrócić uwagę, że Szwajcaria stała się jednym ze światowych liderów technologicznych w XIX wieku bez posiadania prawa patentowego. Chemicznych substancji nie można było opatentować w tym państwie do 1978 roku, a produktów farmaceutycznych nie można było opatentować w Hiszpanii i Kanadzie aż do wczesnych lat 90. XX wieku [Chang 2008].

Oczywistym problemem mającym związek z innowacjami jest koszt ich uzyskania i niepewny efekt sukcesu rynkowego ${ }^{1}$. Prywatni przedsiębiorcy starają się dlatego o prywatną ochronę patentową swoich wynalazków. Z założenia zatem prywatne ryzyko ma przenieść się na prywatne zyski, okazuje się jednak w pewnych przypadkach, że to całe społeczeństwa partycypują w kosztach osiągnięcia innowacji i prywatnych zysków korporacji, choć jest to odwleczone w czasie. W przemyśle farmaceutycznym i medycznym innowacje stają się realnie dostępne dla pacjentów dopiero po dopłatach z budżetów państw. Innowacje $\mathrm{w}$ rolnictwie bywają także dużym obciążeniem budżetowym z racji dopłat na poziomie poszczególnych państw, ale także $\mathrm{w}$ ramach wspólnej polityki rolnej UE. Są to przykłady, kiedy państwa płacą za prywatną inicjatywę.

Olbrzymie znaczenie dla innowacyjności mają instytucje. Wszelkie naciski państw bez odpowiednich uwarunkowań instytucjonalnych będą nieefektywne. Można tu też wspomnieć o kulturze innowacyjności, którą państwa posiadają lub też nie. Instytucje nie są jednak czymś stałym i istnieje możliwość ich transferu, adaptacji, a także mogą być przedmiotem innowacji [Chang 2003]. Przykład gospodarek Azji Wschodniej pokazuje, że wzrost gospodarczy państw zależy od tego, czy uda im się import, adaptacja, asymilacja i innowacja instytucji, a nie tylko technologii. Westney [1987] wykazał, że Japonia z czasów okresu Meiji zaadoptowała system prawa handlowego z Francji, prawo karne z Niemiec, bank

\footnotetext{
${ }^{1}$ Poza tym pewne rodzaje innowacji przyczyniają się wręcz do destabilizacji rynków i gospodarek państw - np. innowacje finansowe w dobie kryzysu 2007/2008.
} 
centralny z Belgii, marynarkę wojenną z Wielkiej Brytanii, armię z Niemiec, a także system edukacyjny z Niemiec, gdy okazało się, że amerykańska wersja wcześniej się nie sprawdziła.

W obliczu konkretnych instytucji i kultury wydaje się, że Polska ma szczególnie duży problem związany z innowacyjnością. Na taki aspekt zwracają uwagę autorzy opracowania pod redakcją Jacka Żakowskiego [2015], zwłaszcza Janusz Czapiński. Wskazuje on na parę elementów, które nie pozwalają Polakom na rozwinięcie swojego potencjału. Należą do nich:

- zamknięte sieci społeczne - jeśli sieci społeczne są „dziurawe”, tzn. gdy ludzie rozwijają swoje kontakty poza swoje znane środowiska, to zapobiegaja głębokim podziałom i tworzą podatny grunt pod innowacje, bo wymiana informacji to niezbędny warunek rozwoju. Polacy zazwyczaj tkwią od wieków w sieciach zamkniętych i nie zmieniają tego technologie komunikacyjne. Skłonność ta jest uwarunkowana kulturowo;

- patologiczny indywidualizm - cechuje on Polaków i Węgrów, co utrudnia współpracę, rozwój kapitału społecznego, budowanie zespołów projektowych i społeczeństwa obywatelskiego. Wyróżnikiem polskiego indywidualizmu jest to, że nakłada się na niego orientacja na dominację społeczna, co skłania do rywalizacji wszystkich ze wszystkimi. Dominacja ta jest odzwierciedlana w budowaniu hierarchii, powiększaniu dystansów moralnych, ideowych i tych zwiazzanych ze statusem społecznym;

- deficyt transgresji - kultury transgresyjne przejawiają się w przekraczaniu granic dotychczasowych wzorców odczuwania, zachowania, myślenia. Ich przeciwieństwem są kultury zachowawcze, które podtrzymują tradycyjne wzorce. Polaków cechuje duża zachowawczość, nawet w nauce polskiej głównie stosuje się naśladownictwo. Do tego dochodzi silna awersja do ryzyka, lęk przed nowym, niechęć do obcych;

- nieufność - ta cecha Polaków jest na stabilnym i wysokim poziomie od 25 lat i wyróżnia nas wśród społeczeństw europejskich.

Mimo istnienia różnych recept na wzrost innowacyjności, wobec wymienionych wcześniej czynników, jest wielce prawdopodobne, że wszelkie przykazania będą w Polsce nieefektywne. Parki naukowo-technologiczne i różne inkubatory przedsiębiorczości, oczywiście poza małymi wyjątkami, będą w rzeczywistości sprowadzały swoje funkcje do wynajmu powierzchni biurowej. Jest to problem najtrudniejszy do pokonania, bo wynika z polskiej mentalności i ma charakter psychologiczny, socjologiczny i kulturowy. Być może podejście do tej kwestii z takiej perspektywy mogłoby, przy długofalowym i odpowiednim podejściu do systemu edukacji od najniższego szczebla, przynieść oczekiwane rezultaty. Niestety takie efekty nie będą nigdy pokrywać się z „cyklem wyborczym”. 


\section{Alternatywa wobec innowacyjności}

Według kryterium legalności istnieją dwa rodzaje alternatyw wobec innowacji: nielegalne (kradzież, szpiegostwo przemysłowe, itd.) i legalne (imitacja, zakupy). Wśród nich najlepsza wydaje się być imitacja, która nie ma wad innowacji, a jedynie ma jej zalety. Zakupy nie odgrywają większej roli z powodu małej podaży i wysokich cen. Imitacja nie może jednak polegać na zwykłym kopiowaniu. Przykłady państw Azji Wschodniej (np. japoński Lexus) pokazują że właściwym sposobem postępowania jest obserwacja innowatorów, a następnie analiza ich innowacji. Kolejnym krokiem jest stworzenie czegoś jeszcze lepszego, a przynajmniej pozbawionego tylu wad co oryginał, przy jednoczesnym i silnym nacisku na konkurencyjność cenową proponowanych rozwiązań.

Imitowanie wydaje się być idealną strategią, zwłaszcza jeśli jest traktowana jako etap rozwoju w osiąganiu innowacyjności. Taką długofalową strategię można zauważyć u Chińczyków, analizując ich osiągnięcia innowacyjne od starożytności do współczesności. Praktycznie przez cały czas nauka w Chinach była ukierunkowana na naśladowanie tego, co było, a nie na tworzenie rzeczy nowych. Sam Konfucjusz mawiał: „Przekazuję jeno nauki starożytnych, lecz sam niczego nie tworzę" [Künstler 2007]. Postawa taka wcale nie musi charakteryzować się pasywnością. Na całym świecie trwa bardzo aktywne poszukiwanie interesujących pomysłów, które można skopiować. Dotyczy to absolutnie wszystkich państw i Chińczyków nie można tutaj wyróżniać. Polska w taki sposób zdobyła na przykład Polopirynę w latach 80 . XX wieku, a o wielu innych tego typu osiągnięciach nie pisze się artykułów naukowych z oczywistych względów. Działania takie są tym bardziej uzasadnione, że 97,8\% wartości innowacji przechodzi w ręce imitatorów [Shenkar 2010]. Landes [2007] opisuje, że kopiowanie było zawsze obecne w historii gospodarczej.

Spektakularne osiagnięcia chińskich wynalazców mogą prowokować pytania o jakość ich rozwiązań i patentów. Jest to uzasadnione, ponieważ Chińczyków cechuje kulturowo uwarunkowana „choroba prestiżu”. Należy zauważyć, że w Chinach dokonuje się wielu dużych postępów, a jakość tych zmian stale jest poprawiana. Chińscy fachowcy, przynajmniej w niektórych dziedzinach, należą już do światowej czołówki, projektując najszybsze komputery i telefonię komórkową piątej generacji, czy edytując geny i prowadząc eksperymentalne terapie medyczne. Chińczycy produktywnie wykorzystują okres imitacji, szybciej i łatwiej tworząc później innowacje. To także może być uwarunkowane kulturowo. Yip i McKern [2016] wskazuja, że konsumenci Państwa Środka szybko przyswajają nowe trendy i potrafią wybaczać rynkowe błędy, co pozwala przedsiębiorcom na eksperymentowanie i uczenie się poprzez robienie, czyli nabywanie tzw. tacit knowledge. Sprzyja temu rosnąca klasa średnia. 
Istnieje koncepcja tzw. otwartych innowacji, która de facto ma wiele wspólnego z naśladownictwem już powstałych rozwiązań, czyli z imitacją. Głosi ona, że powinno wykorzystywać się zewnętrzne i wewnętrzne pomysły (np. w przedsiębiorstwach), ale też zewnętrzne i wewnętrzne kanały dyfuzji innowacji. Otwarte innowacje są pochodną różnego rodzaju wiedzy, która zawsze jest potrzebna wszystkim jednostkom gospodarującym. Chesbrough [2003, s. 26] wymienia cechy tego paradygmatu, ale wśród nich najbliższe imitacji wydają się być następujące:

- prowadzenie i inicjacja badań nie są konieczne do osiagania z nich zysków,

- tworzenie lepszych modeli biznesowych jest preferowane od bycia pierwszym na rynku,

- czerpanie korzyści, gdy inni wykorzystują naszą własność intelektualną, ale kupowanie obcej własności intelektualnej tylko wtedy, gdy jest to ekonomicznie uzasadnione.

Imitacja jest nieodłącznym elementem innowacji. Jest ona w zasadzie często ujmowana jako druga strona innowacji [Kleer 2015]. Z racji, że innowacje (koszty i niepewny efekt rynkowy) mają istotne wady, warto ją rozważyć, ale nie tylko w kontekście technologii. Niezmiernie istotne jest stworzenie odpowiednich warunków, które pozwolą na rozwój technologii. Warunki te stanowią instytucje i odpowiednia kultura. Sednem tej drugiej są wartości i prowadząc takiego typu rozważania, należy patrzeć przez ich pryzmat.

\section{Wnioski}

Innowacyjność to proces oddolny, w znacznej mierze niezależny od politycznych decydentów. Droga do niego jest obarczona dużym ryzykiem, chociaż premia za bycie pierwszym bywa głównym motywatorem działania jednostek gospodarujących. Do innowacyjności państwo, branża, gałą́ przemysłu, przedsiębiorstwo muszą dojrzeć, tzn. osiagnąć odpowiedni etap rozwoju. Jest to ważne, aby uniknąć losu wynalazków Leonarda da Vinci, które wyprzedzały swoją epokę. O tym etapie rozwoju jak najbardziej decydują także odpowiednie instytucje i kultura (choćby organizacyjna w przedsiębiorstwie).

O ile innowacje są jak rewolucja, o tyle imitacje przypominają bardzo ewolucję. Równie powolny bywa ich rozwój, ale ewolucja nie przynosi zazwyczaj ofiar. Jedne nie mogą zastapić drugich, ale powinny istnieć obok siebie, stanowiąc wzajemne źródło inspiracji. Historyczna droga tego współistnienia pokazuje, że kierunek ich rozwoju wygląda następująco: innowacje (cudze) - imitacje (innowacji) - innowacje (własne). Zamiarem autora było zwrócenie uwagi na problemy związane z innowacyjnością i wykazanie, że alternatywa, czyli imi- 
tacje, jest zbyt rzadko obecna w oficjalnych dokumentach różnych jednostek, chociaż jest nieodłącznym elementem innowacyjności.

\section{Literatura}

BARUK J., 2002: Dylematy rozwoju małych i średnich przedsiębiorstw, Gospodarka Narodowa 3, 51-72.

Bloomberg Innovation Index, 2016: These Are the World's Most Innovative Economies, https://www.bloomberg.com/news/articles/2016-01-19/these-are-the-world-s-most-innovative-economies [dostęp: 01.12.2016].

CASTENOW D., 1996: Nowy marketing $w$ praktyce, PWE, Warszawa.

CHANG H.-J., 2003: The East Asian Development Experience, [w:] H-J. Chang (red.), Rethinking Development Economics, Anthem Press, London.

CHANG H-J., 2007: Kicking Away the Ladder. Development Strategy in Historical Perspective, Anthem Press, London.

CHANG H-J., 2008: Bad Samaritans. The Myth of Free Trade and the Secret History of Capitalism, Bloomsbury Press, New York.

CHESBROUGH H., 2003: Open Innovation. The New Imperative for Creating and Profiting from Technology, Harvard Business School Press, Boston.

EDISON H., ALI N.B., TORKAR R., 2013: Towards innovation measurement in the software industry, Journal of Systems and Software 86 (5), 1390-1407.

Global Innovation Index, 2016: The Global Innovation Index Report, https://www.globalinnovationindex.org/gii-2016-report [dostęp: 01.12.2016].

KLEER J., 2015: Rozwój imitacyjny: zalety i wady, [w:] B. Fiedor (red.), Nauki ekonomiczne. Stylizowane fakty a wyzwania wspótczesności, PWE, Warszawa.

KOTLER P., 1994: Marketing. Analiza, planowanie, wdrażanie i kontrola, Gebethner i Ska, Warszawa.

KÜNSTLER M.J., 2007: Dzieje kultury chińskiej, Wydawnictwo Naukowe PWN, Warszawa.

LANDES D.S., 2007: Bogactwo i nędza narodów. Dlaczego jedni sq tak bogaci, a inni tak ubodzy, Muza, Warszawa.

NASIEROWSKI W., 1997: Zarzqdzanie rozwojem techniki, Poltext, Warszawa.

POMYKALSKI A., 2001: Zarzadzanie innowacjami, Wydawnictwo Naukowe PWN, Warszawa.

RODRIK D., 2007: One Economics, Many Recipes. Globalization, Institutions, and Economic Growth, Princeton University Press, Princeton.

SCHUMPETER J.A., 1934/2012: The Theory of Economic Development. An Inquiry into Profits, Capital, Credit, Interest, and the Business Cycle, Transaction Publishers, New Brunswick.

SHENKAR O., 2010: Copycats: How Smart Companies Use Imitation to Gain a Strategic Edge, Harvard University Press, Boston.

SOLOW R.M., 1957: Technical Change and the Aggregate Production Function, Review of Economics and Statistics 39, 312-320. 
WESTNEY E., 1987: Imitation and Innovation: The Transfer of Western Organisational Patterns to Meiji Japan, Cambridge University Press, Cambridge.

WIPO Statistics Database, 2016: Total count by filling office, http://ipstats.wipo.int/ipstatv2/ IpsStatsResultvalue [dostęp: 01.12.2016].

YIP G., McKERN B., 2016: China's Next Strategic Advantage. From Imitation to Innovation, MIT Press, Cambridge.

ŻAKOWSKI J. (red.), 2015: Reforma kulturowa 2020-2030-2040, Sukces wymaga zmian, Kongres Innowacyjnej Gospodarki, Warszawa, https://www.kig.pl/files/Aktualnosci/ KIG_RAPORT.pdf [dostęp: 29.10.2016].

\section{Abstrakt}

Autor porusza problematykę innowacji i innowacyjności, zwracając uwagę na ich wady. Innowacje są pożądane przez państwa i korporacje, ale ich implementacja nie zawsze jest udana z powodu braku odpowiedniego otoczenia instytucjonalnego i kulturowego. Niedocenionym źródłem przewagi konkurencyjnej mogą być imitacje, które nie mają tylu wad co innowacje, a mogą do nich także prowadzić.

Słowa kluczowe: innowacje, imitacje, instytucje, kultury, ekonomia

\section{Critical analysis of the innovation paradigm}

\section{Abstract}

The autor raises the issue of innovation and pays attention to its disadvan tages. Although innovations are the aim of many states and corporations their implementation is not always successful. The reason is lack of proper institutional and cultural background. Imitations may be an underrated source of competitive advantage. They do not have so many disadvantages as innovations but may lead to them as well.

Key words: innovations, imitations, institutions, cultures, economics 
Tabela 1

Liczba przyznanych patentow i dynamika ich przyrostu w latach 2005-2015

\begin{tabular}{|c|c|c|c|c|c|c|c|c|c|c|c|c|c|c|c|c|c|c|c|c|c|}
\hline \multirow[b]{2}{*}{$\begin{array}{l}\text { Wyszcze- } \\
\text { gólnienie }\end{array}$} & \multirow{2}{*}{ 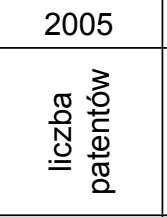 } & \multicolumn{2}{|c|}{2006} & \multicolumn{2}{|c|}{2007} & \multicolumn{2}{|c|}{2008} & \multicolumn{2}{|c|}{2009} & \multicolumn{2}{|c|}{2010} & \multicolumn{2}{|c|}{2011} & \multicolumn{2}{|c|}{2012} & \multicolumn{2}{|c|}{2013} & \multicolumn{2}{|c|}{2014} & \multicolumn{2}{|c|}{2015} \\
\hline & & 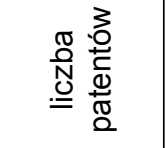 & 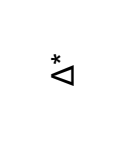 & 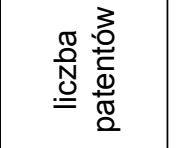 & 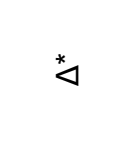 & 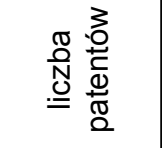 & $\star *$ & 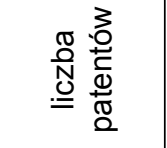 & $\stackrel{*}{\triangleleft}$ & 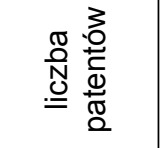 & 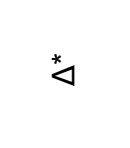 & 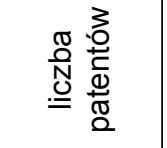 & $\star *$ & 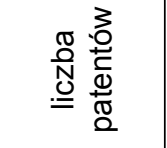 & 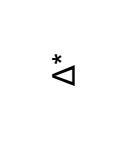 & 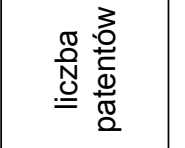 & 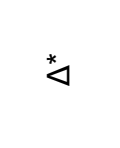 & 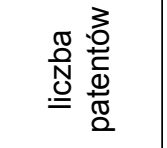 & $\star *$ & 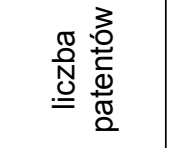 & $\stackrel{*}{\triangleleft}$ \\
\hline Chiny & 173327 & 210501 & 121,45 & 245161 & 116,47 & 289838 & 118,22 & 314604 & 108,54 & 391177 & 124,34 & 526412 & 134,57 & 652777 & 124,00 & 825136 & 126,40 & 928177 & 112,49 & 1101864 & 118,71 \\
\hline USA & 390733 & 425966 & 109,02 & 456154 & 107,09 & 456321 & 100,04 & 456106 & 99,95 & 490226 & 107,48 & 503582 & 102,72 & 542815 & 107,79 & 571612 & 105,31 & 578802 & 101,26 & 589410 & 101,83 \\
\hline Japonia & 427078 & 408674 & 95,69 & 396291 & 96,97 & 391002 & 98,67 & 348596 & 89,15 & 344598 & 98,85 & 342610 & 99,42 & 342796 & 100,05 & 328436 & 95,81 & 325989 & 99,25 & 318721 & 97,77 \\
\hline $\begin{array}{l}\text { Korea } \\
\text { Południowa }\end{array}$ & 160921 & 166189 & 103,27 & 172469 & 103,78 & 170632 & 98,93 & 163523 & 95,83 & 170101 & 104,02 & 178924 & 105,19 & 188915 & 105,58 & 204589 & 108,30 & 210292 & 102,79 & 213694 & 101,62 \\
\hline Niemcy & 60222 & 60585 & 100,60 & 60992 & 100,67 & 62417 & 102,34 & 59583 & 95,46 & 59245 & 99,43 & 59444 & 100,34 & 61340 & 103,19 & 63167 & 102,98 & 65965 & 104,43 & 66893 & 101,41 \\
\hline Francja & 17275 & 17249 & 99,85 & 17109 & 99,19 & 16419 & 95,97 & 15693 & 95,58 & 16580 & 105,65 & 16754 & 101,05 & 16632 & 99,27 & 16886 & 101,53 & 16533 & 97,91 & 16300 & 98,59 \\
\hline Singapur & 8605 & 9163 & 5,48 & 9951 & 108,60 & 9692 & 40 & 8736 & 90,14 & 9773 & 111,87 & 9794 & 100,21 & 9685 & 98,89 & 9722 & 100,38 & 10312 & 106,07 & 10814 & 104,87 \\
\hline Szwecja & 2960 & 59 & & 925 & & 2855 & & 2649 & & 2549 & & 2341 & & 2436 & & 2495 & 102,42 & 2425 & & 2428 & 100,12 \\
\hline Szwajcaric & 2098 & 2102 & 100,19 & 2034 & 96,76 & 2033 & 99,95 & 2078 & 102,21 & 2155 & 103,71 & 2043 & 94,80 & 2988 & 146,26 & 2156 & 72,16 & 2048 & 94,99 & 1923 & 93,90 \\
\hline Dania & 1823 & 1691 & 92,76 & 1857 & 109,82 & 1829 & 98,49 & 1649 & 90,16 & 1768 & 107,22 & 1771 & 100,17 & 1635 & 92,32 & 1534 & 93,82 & 1583 & 103,19 & 1732 & 109,41 \\
\hline Finlandia & 2059 & 2018 & & 2015 & & 1946 & & 1933 & & 1833 & 94,83 & 1774 & 96,78 & 1827 & 102,99 & 1737 & 95,07 & 1545 & 88,95 & 1416 & 91,65 \\
\hline Polska & 583 & 312 & & 2753 & & 2778 & & 3140 & 113 & 3430 & 9,24 & 4123 & 120,20 & 4657 & 112,95 & 4411 & 94,72 & 4096 & 92,86 & 4815 & 117,55 \\
\hline Europa & 326000 & 333100 & 102,18 & 339300 & 101,86 & 345900 & 101,95 & 323400 & 93,50 & 343300 & 106,15 & 334100 & 97,32 & 345800 & 103,50 & 345900 & 100,03 & 346100 & 100,06 & 360000 & 104,02 \\
\hline Azja & 854600 & 889700 & 104,11 & 932400 & 104,80 & 980000 & 105,11 & 944000 & 96,33 & 1028800 & 108,98 & 1178800 & 114,58 & 1321200 & 112,08 & 1497700 & 113,36 & 1607400 & 107,32 & 1786800 & 111,16 \\
\hline Afryk & 900 & 12800 & & 14100 & & 13800 & & 12300 & 89 & 12400 & 100,81 & 14500 & 116,94 & 14700 & 101,38 & 14600 & 99,32 & 15000 & 102,74 & 14800 & 98,67 \\
\hline Świat & 1702800 & 1791000 & 8,18 & 74200 & 104,65 & 1929200 & 102,93 & 1855200 & 96,16 & 1997000 & 107,64 & 2158100 & 108,07 & 2356700 & 109,20 & 2564900 & 108,83 & 2680900 & 104,52 & 2888800 & 107,75 \\
\hline
\end{tabular}

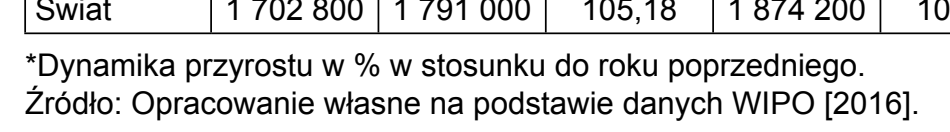

